\title{
Guiding principles for the development of mental health policies in low- and middle- income countries
}

\section{Princípios que devem nortear as políticas de saúde mental em países de baixa e média rendas}

Recently, the World Psychiatric Association Task Force, led by Professor Graham Thornicroft, drew the guidelines for taking the necessary steps towards the implementation of a communitybased mental health care program and for overcoming obstacles and avoiding mistakes preventing this. ${ }^{1}$ The Task Force's main recommendations address the need for coordinated policies, plans and programs, the requirement to scale up services for entire populations, the importance of promoting community awareness about mental illness to increase levels of help-seeking, and the need to establish effective financial and budgetary provisions to offer direct support services to the community. According to this report and other articles on the subject, there are many principles that should be used to guide mental health policies.

However, rather than compiling a long list of principles, I wish to bring into focus two important but often neglected concepts, i.e., - Recovery and Consumer involvement. It is my belief that any mental health policy should aim at and promote the recovery of a person with mental health problems. To be successful, such policy should take into consideration the needs of consumers.

\section{Recovery}

The concept of "recovery" is a rather an ambiguous one. Although different definitions for recovery have been proposed by different authors, I would like to rely mainly on the traditional definition provided by Anthony ${ }^{2}$ :

"Recovery is a deeply personal, unique process of changing one's attitudes, values, feelings, goals, skills, and/or roles. It is a way of living a satisfying, hopeful, and contributing life even with limitations caused by illness."

In the last thirty years, the idea of recovery has became universally accepted. To illustrate this, an increasing number of countries have either incorporated the term recovery into their mental health policy vocabulary or have somehow adopted this idea. New Zealand was one of the first countries to include the term recovery in policy making. In 1998, New Zealand's national mental health service development plan, also called the Blueprint, ${ }^{3}$ clearly states that "the focus of this Blueprint is the adoption of a recovery-based approach in service delivery."

Similarly, in the US, the President's New Freedom Commission on Mental Health, which was established in 2001 to conduct a comprehensive study on the U.S. mental health service delivery system and make recommendations based on its findings, wrote a report ${ }^{4}$ whose vision statement begins as follows: "We envision a future when everyone with a mental illness will recover, a future when mental illnesses can be prevented or cured, a future when mental illnesses are detected early, and a future when everyone with a mental illness at any stage of life has access to effective treatment and support, which are essential for living, working, learning, and participating fully in the community."

The individual recovery of consumers, however, does not depend on policy making alone: recovery-oriented services must be universally provided and every consumer, his or her family, service providers, administrators, and policy makers need to believe in this recovery. There is a need for these services to actually assist people in their processes towards recovery.

\section{Consumer involvement}

Historically, people with mental illnesses have been seen as people in need of protection and with limited ability to participate in the development of the mental health service system. However, since recovery is what people with disabilities aim at and considering that service providers are engaged in facilitating this recovery, policies geared towards any recovery must involve consumers right at the start of the policy-making process. The Alma-Ata Declaration ${ }^{5}$ supports this in its Article 4, which states that "The people have the right and duty to participate individually and collectively in the planning and implementation of their health care."

I would like to present a recent example of a Japanese initiative in which consumers and their families actively participated in the policy-making process. In April 2010, a voluntary body called the Mental Health Policy Framing Conference was set up with the presence of the Minister of Health, Labour and Welfare. In May 2010, after serious discussions, conference participants submitted a Recommendation Letter to the Minister. What set this Conference apart from other conferences was that 30\% of all committee members were either consumers or their family members, and that a significant amount of time was dedicated to listening to their needs. As a result, this Recommendation Letter was entirely based on the needs of consumers and their families. 
In certain countries, this work may have to begin by developing and organizing family and consumer groups, both locally and nationally, so that these people can speak for themselves - "Nothing about us without us!"

Some people may argue, as was the case in Japan, that there aren't any consumers who want to speak up. Ten years ago, there were not many consumers willing to stand for themselves and speak their minds. However, more recently, we find that there are many consumers who want to talk about their own experiences. In other words, when given the chance, they are eager to talk. What we need to do is to patiently and respectfully listen to their needs.

In conclusion, when it comes to developing mental health policies not only in low- and middle- income countries, policy makers should aim at promoting the recovery of individuals by involving consumers. This should be so not because it is politically correct, but because consumers are the only ones who truly know their needs.

\section{Yutaro Setoya}

National Institute of Mental Health (NIMH), National Center of Neurology and Psychiatry, Japan

\section{Disclosures}

\begin{tabular}{|c|c|c|c|c|c|c|c|}
\hline $\begin{array}{l}\text { Writing group } \\
\text { member }\end{array}$ & Employment & $\begin{array}{c}\text { Research } \\
\text { grant }^{1}\end{array}$ & $\begin{array}{c}\text { Other research grant } \\
\text { or medical continuous } \\
\text { education }{ }^{2}\end{array}$ & $\begin{array}{l}\text { Speaker's } \\
\text { honoraria }\end{array}$ & $\begin{array}{l}\text { Ownership } \\
\text { interest }\end{array}$ & $\begin{array}{c}\text { Consultant/ } \\
\text { Advisory } \\
\text { board }\end{array}$ & Other ${ }^{3}$ \\
\hline \multirow[t]{2}{*}{ Yutaro Setoya } & $\mathrm{NIMH}$ & $\begin{array}{c}\text { Intramural } \\
\text { Research Grant } \\
\text { for Neurological } \\
\text { and Psychiatric } \\
\text { Disorders } \\
\text { of NCNP, } \\
\text { Japan }\end{array}$ & - & - & - & - & - \\
\hline & & $\begin{array}{c}\text { Health and } \\
\text { Labour Science } \\
\text { Research, } \\
\text { Japan* }\end{array}$ & & & & & \\
\hline
\end{tabular}

${ }^{*}$ Modest

** Significant

*** Significant: Amounts given to the author's institution or to a colleague for research in which the author has participation, not directly to the author.

Note: $N I M H=$ National Institute of Mental Health, Japan; NCNP = National Center of Neurology and Psychiatry.

For more information, see Instructions for Authors.

References

1. Thornicroft G, Alem A, Santos RA, Barley E, Drake R, Gregorio G, Hanlon C, Ito H, Latimer E, Law A, Mari JJ, McGeorge P, Padmavati R, Razzouk D, Semrau M, Setoya Y, Thara R, Wondimagegn D. WPA guidelines on steps, obstacles and mistakes to avoid in the implementation of community mental health care. World Psychiatry. 2010;9(2):67-77.

2. Anthony WA. Recovery from mental illness: the guiding vision of the mental health service system in the 1990s. Psychosoc Rehabilitation J. 1993;16(4):11-23.

3. Mental Health Commission. Blueprint for mental health services in New Zealand. How things need to be. The Mental Health Commission: Wellington; 1998.

4. President's New Freedom Commission on Mental Health. Achieving the promise: transforming mental health care in America. Department of Health and Human Services, President's New Freedom Commission on Mental Health; 2003.

5. World Health Organization - WHO. Declaration of Alma-Ata. International Conference on Primary Health Care, Alma-Ata; 1978 Sep 6-12. 